\title{
Climate Change Science Activities of the U.S. Geological Survey in New England
}

The U.S. Geological Survey (USGS) has actively pursued research in the effects of climate change on the hydrology of New England. Ongoing focus areas of climate change science activities of the USGS in New England include the following:

- Hydrologic climate-response data collection (initiating or expanding long-term hydrologic climate-response data collection networks to detect and monitor climate-related changes in hydrology)

- Relations between historical climatic and hydrologic variation (investigating historic relations between long-term climatic variation and hydrologic variation and connecting these relations to future conditions as forecasted by the Interagency Panel on Climate Change [Nakićenović and others, 2000])

- Hydrologic change on natural and human systems (incorporating climate change scenarios into assessments of how flows in streams or water levels in aquifers may change)

- Relations between climatic and hydrologic variation (characterizing impacts of climate change on floods and droughts, the long-term availability of water supplies for societal and natural uses in response to climate changes)

- Developing tools to forecast ecosystem change and water resources management (developing regionally consistent tools for forecasting ecosystem change and resource management)

This fact sheet presents recent climate change investigations of the USGS in New England using selected recent publications. These publications highlight the broad spectrum of expertise and commitment to understanding the relations of climate change and water resources in New England.

\section{Hydrologic Climate-Response Data Collection}

The USGS has expanded existing hydrologic data collection networks to address current and future water information needs related to climate change. Recent activities include installation of new data-collection stations to improve ambient monitoring, monitoring of additional parameters, such as water temperature, at critical locations, and collaboration with other Federal and State agencies and universities in climate-related activities at USGS data-collection stations.

\section{Framework for a Hydrologic Climate-Response Network} in New England

Many climate-related hydrologic variables in New England have changed in the past century and are expected to continue to change in the coming years. It is important to understand and monitor changes in hydrologic variables because they can affect human water supply, hydroelectric power generation, transportation infrastructure, and stream and riparian ecology. The framework identifies specific inland hydrologic variables that are sensitive

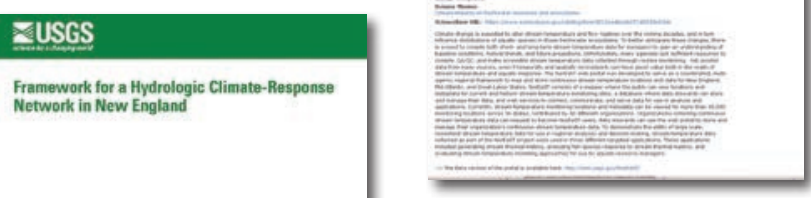

streamflow, groundwater, lake ice, snowpack, and meteorological data-collection networks stations for evaluation of hydrologic response to climate variation. Publication at http://pubs.er.usgs.gov/publication/ofr20151062.

\section{NorEaST Stream Temperature}

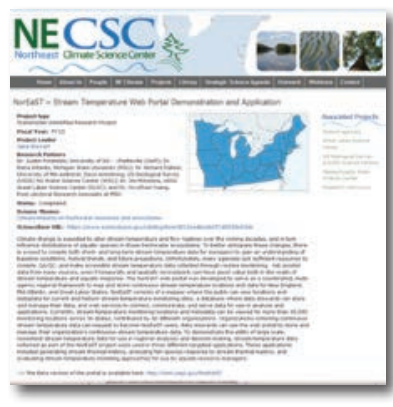

The NorEaST Web portal (https://necsc.umass.edu/ projects/noreast- $\%$ E2\%80\%93stream-temperature-web-portaldemonstration-and-application) was developed to serve as a coordinated multiagency regional framework to map and store continuous stream temperature locations and data for States in New England and the mid-Atlantic and Great Lakes

regions. Stream temperature data and metadata, contributed by 41 different organizations, can be viewed for nearly 7,900 monitoring station across 22 States. The objectives of the project are to identify common data fields and structures that are state-ofthe-art for maintaining water-quality data, conduct user testing to refine the Web portal for data access and management purposes, and develop and apply models to demonstrate the utility of large scale, consistent stream temperature data in decision making. The common data fields and structures are used to build a data template and framework to store incoming stream temperature data, build Web services to output these standards, and format select datasets to demonstrate applications of these data. 


\section{Relations Between Historical Climatic and Hydrologic Variation}

The USGS has completed numerous studies to evaluate the relation between of long-term climatic and hydrologic variation; trends in streamflow regimes, groundwater levels, and climatological variables are evaluated to determine the important processes controlling hydrologic response to climate change.

\section{Effects of Climate Change on Snowmelt-Dominated Groundwater Resources of Northern New England}

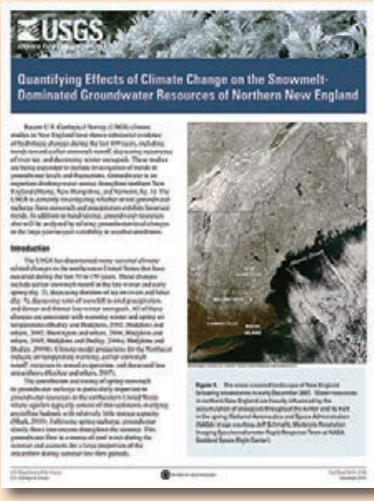

Northern New England

(Maine, New Hampshire, and

Vermont) is an ideal region to monitor the effects of climate change on groundwater resources because water resources in the region are dominated by snowmelt hydrology and the region is largely undeveloped, thus effects from water use on groundwater are limited. Analyses of historical snowpack and streamflow data in northern New England have demonstrated that snowpack, snowmelt runoff, and summer base flows have changed substantially during the last 100 years. This project examined interannual correlations between the historical groundwater levels across northern New England and seasonal air temperatures and precipitation to define the sensitivity of groundwater levels to these variables. Publication at http://pubs.er.usgs.gov/publication/fs20103104.

\section{Historical Changes in Annual Peak Flows in Maine}

There is evidence that peak flows on rivers in Maine have increased during the past 50 years, and bridges and culverts could therefore be currently underdesigned. In a cooperative project with the Maine Department of Transportation, maximum annual streamflow-trend magnitudes were investigated for 28 stream gages in Maine that had at least 50 years of data. Peak flows for selected recurrence intervals are sensitive to very high peak flows that may occur once in a century or even less frequently. Therefore, it is difficult to determine which approach will produce the most reliable future estimates of peak flows for selected recurrence intervals - using only recent years of record or the traditional method using the entire historical period. One possible conservative approach to computing peak flows of selected recurrence intervals would be to compute peak flows using recent annual peak flows and the entire period of record and then choose the higher computed value. Publication at http://pubs.er.usgs.gov/publication/sir20105094.

\section{Hydrologic Change on Natural and Human Systems}

Collection and analysis of field data have been used to understand the relation between hydroclimatological change and critical societal issues, including floods, droughts, ecosystem health, water quality, and urban environments.

\section{Predicting Inundation of Salt Marshes in Response to Sea- Level Rise in and Around Acadia National Park}

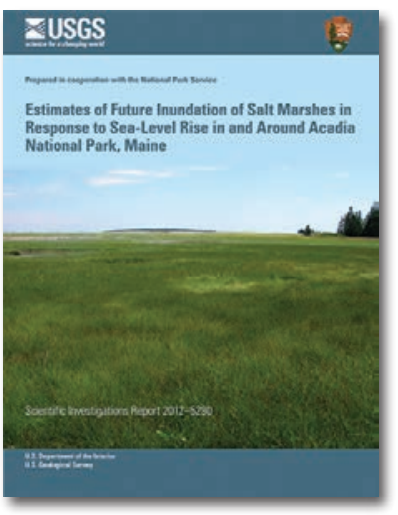

Recent USGS climate studies in the northeastern United States have shown substantial evidence of climate-related changes during the past 100 years, including snowmelt runoff occurring earlier in the year, decreasing occurrence of river ice, and decreasing winter snowpack. These climate changerelated studies are being expanded to include investigation of coastal wetlands that might be at risk from sea-level rise. Coastal wetlands,

particularly salt marshes, are important ecosystems that provide habitats for wildlife nursery and breeding and for migratory birds, enhancements to water quality, and control measures against shoreline erosion. The USGS investigated salt marshes in Acadia National Park with the goal of determining which salt marshes may be threatened by sea-level rise and which salt marshes may be able to adapt to sea-level rise by migrating into adjacent low-lying lands. Publication at http://pubs.er.usgs.gov/ publication/sir20125290.

\section{Effects of Ground-Water Pumping and Sea-Level Change, Lower Cape Cod Aquifer System}

The USGS conducted an investigation to improve the understanding of the hydrogeology of the four freshwater lenses of the lower Cape Cod aquifer system and to assess the effects of changing groundwater pumping, recharge conditions, and sea level on groundwater flow in lower Cape Cod, Massachusetts. The depth to the freshwater-saltwater interface varies throughout the study area and is directly proportional to the

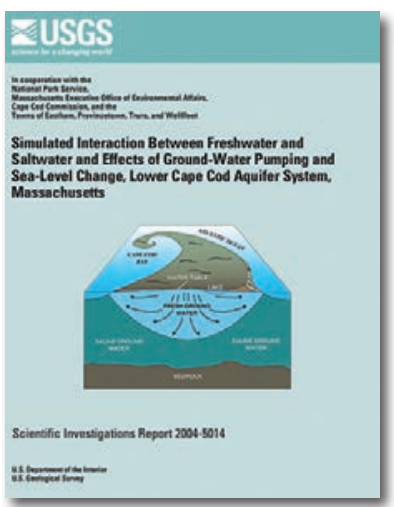
height of the water table above sea level. Simulated increases in sea level appear to increase water levels and streamflows throughout the lower Cape Cod aquifer system, and yet decrease the depth to the freshwater-saltwater interface. Publication at study in cooperation with the Cape Cod Commission is running additional modeling of sea-level rise effects on aquifers on Cape Cod. http://pubs.er.usgs.gov/publication/sir20045014. An ongoing 


\section{Relations Between Climatic and Hydrologic Variation}

Numerical modeling, including the Precipitation Runoff Modeling System and the three-dimensional finite-difference groundwater model MODFLOW, in conjunction with USGS long-term data and field-based studies, were used to evaluate the effects of forecasted changes in precipitation and temperature on hydrologic systems in New England.

\section{Hydrologic Vulnerability to Climate Change in New Hampshire}

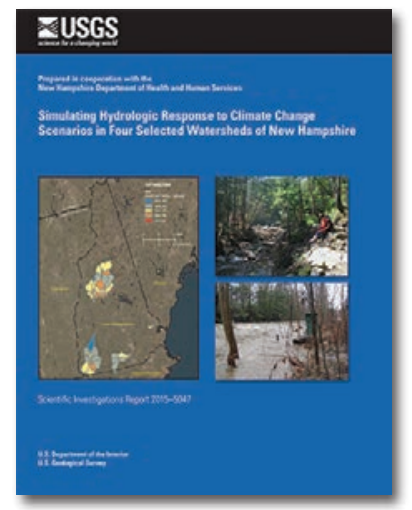

The State of New Hampshire has initiated a coordinated effort to proactively prepare for the effects of climate change on natural and human resources. An important aspect of this effort has been to develop a vulnerability assessment of hydrologic response to climate change. The study was a test case to assemble the information and create the tools to assess the hydrologic vulnerabilities in the watersheds of the Ashuelot,

Oyster, Pemigewasset, and Souhegan Rivers in New Hampshire in the 21 st century; the study simulated streamflow, groundwater base flow, and snowfall in the four watersheds. Simulations show that, on average, relative to current conditions, streamflow is likely to increase and base flow is likely to decrease, although this change is highly variable by geographic location and season. Streamflow variability will likely increase in response to climate change, with more high streamflows and more low streamflows. The largest increases in streamflow are in the winter, with small decreases in summer. Change in base flow varies across the
State, with the largest change being in the northern Pemigewasset watershed. Changes in snowfall are consistently decreasing for all watersheds on average, with the largest change also in the Pemigewasset. However, monthly snowfall totals during any given winter could be higher in the future than expected under current conditions. Publication at http://pubs.er.usgs.gov/ publication/sir20155047. An ongoing study is expanding this test case statewide.

\section{Effects of Climate Change on Groundwater Systems in Rhode Island}

Soil-water balance and groundwater-flow models were developed to delineate the areas that contribute recharge to water-supply wells and to quantify the hydrologic response of the groundwaterflow system to projected 21 st century changes in temperature and precipitation in the Chipuxet and Chickasheen River basins in southern Rhode Island; climate projections were obtained from downscaled general circulation

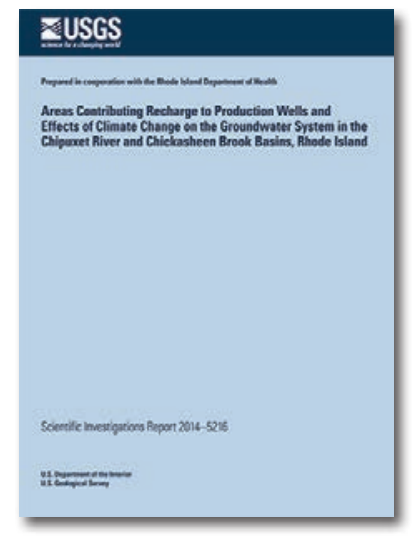
models (Nakićenović and others, 2000). In the case of carbon emissions that continue to increase into the 21 st century, winter groundwater recharge is expected to increase by as much as 15 percent for the higher emissions scenario, and fall groundwater recharge is projected to diminish by as much as 24 percent. Although recharge is projected to change seasonally in the 21 st century, mean annual recharge is expected to change only minimally. Publication at http://pubs.er.usgs.gov/publication/ sir20145216.

\section{Developing Tools for Forecasting Ecosystem Change and Water Resources Management}

The USGS uses statistical and deterministic models to model and forecast seasonal and long-term change. Representative models are used for evaluation and short- and long-term forecasting of the effects of climate change on hydrologic systems to evaluate the effects of water use on water, apply hydrologic knowledge to improve existing or new biological population and survival models, and help emergency management agencies develop emergency response plans.

\section{The Massachusetts Sustainable-Yield Estimator: A Decision-Support Tool To Assess Water Availability at Ungaged Streams in Massachusetts}

Water-resource managers at the Federal, State, and local levels require a variety of data and modeling tools to better understand water resources. The USGS, in cooperation with the Massachusetts Department of Environmental Protection, has developed a statewide interactive decision-support tool to meet this need. The decision-support tool, referred to as the Massachusetts Sustainable-Yield Estimator (MA SYE) provides screening-level estimates of the sustainable yield of a basin; sustainable yield is defined as the difference between the unregulated streamflow and some user-specified quantity of water that must remain in the stream to support such functions as recreational activities or aquatic habitat. The MA SYE tool was designed, in part, because the quantity of surface water available in a basin is a time-variable quantity subject to competing demands for water. Publication at http://pubs.er.usgs.gov/publication/ sir20095227. The USGS, in coopera-

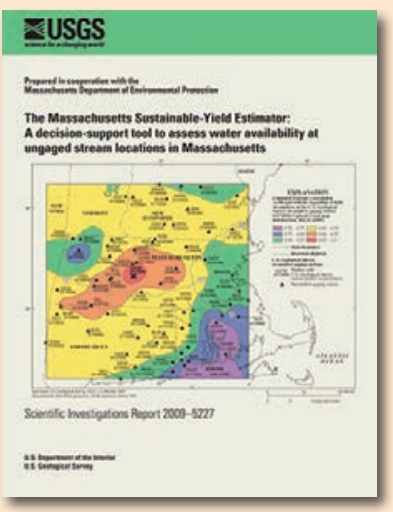
tion with the Commonwealth of Massachusetts, is developing a new version of the MA SYE. 


\section{Reference Cited}

Nakićenović, Nebojša, Alcamo, Joseph, Davis, Gerald, de Vries, Bert, Fenhann, Joergen, Gaffin, Stuart, Gregory, Kenneth, Grübler, Arnulf, Jung, T.Y., Kram, Tom, La Rovere, E.L., Michaelis, Laurie, Mori, Shunsuke, Morita, Tsuneyuki, Pepper, William, Pitcher, Hugh, Price, Lynn, Riahi, Keywan, Roehrl, Alexander, Rogner, H.H., Sankovski, Alexei, Schlesinger, Michael, Shukla, Priyararshi, Smith, Steven, Swart, Robert, van Rooijen, Sascha, Victor, Nadejda, and Zhou Dadi, 2000, Special report on emissions scenarios; A special report of Working Group III of the Intergovernmental Panel on Climate Change: Cambridge, United Kingdom, Cambridge University Press, 599 p. [Also available at http://www.grida.no/publications/other/

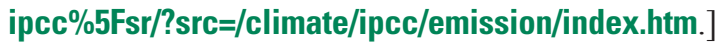

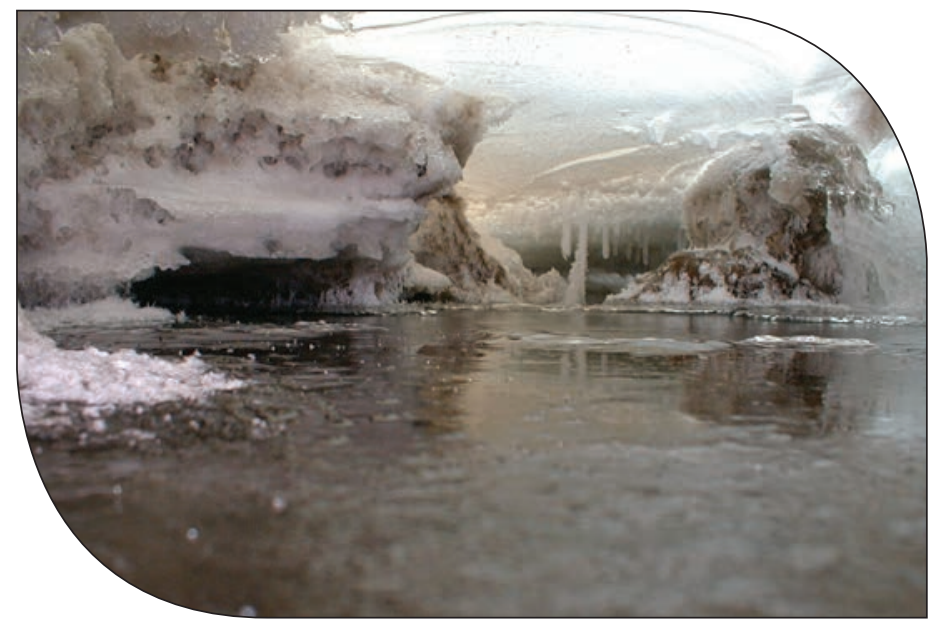

Cold temperatures after a rain event caused an ice layer to form on Libby Brook near Northfield, Maine, and the ice layer remained as water levels dropped in February 2005. Photograph by the U.S. Geological Survey.

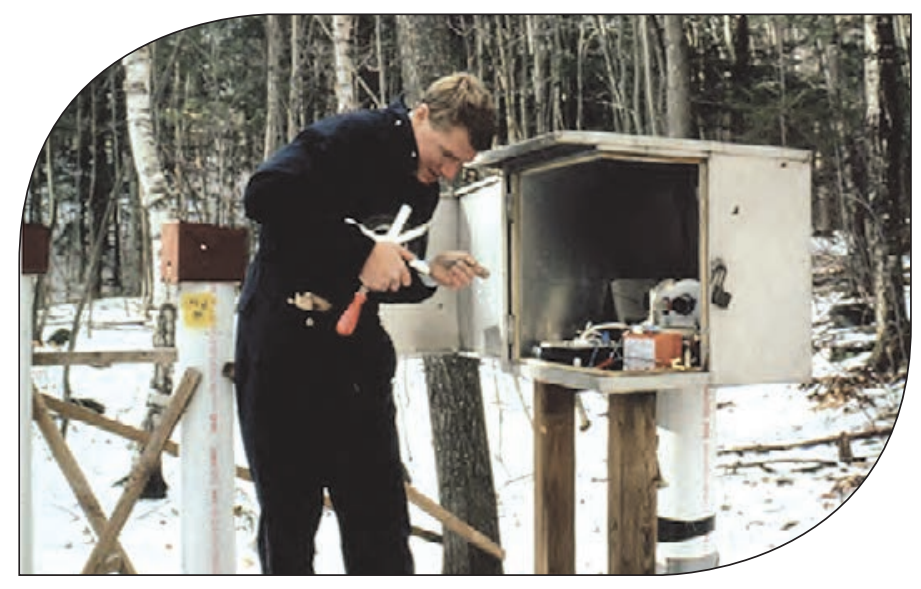

U.S. Geological Survey scientist measures groundwater levels with a steel tape to check the accuracy of an automated water-level measurement system at Mirror Lake groundwater-research site within the Hubbard Brook Experimental Forest in North Woodstock, New Hampshire. Photograph by the U.S. Geological Survey.

\section{For more information, contact:}

Director, New England Water Science Center

U.S. Geological Survey

331 Commerce Way, Suite 2

Pembroke, NH 03275

Email: dc_nweng@usgs.gov

or visit our Web site at

http://newengland.water.usgs.gov/

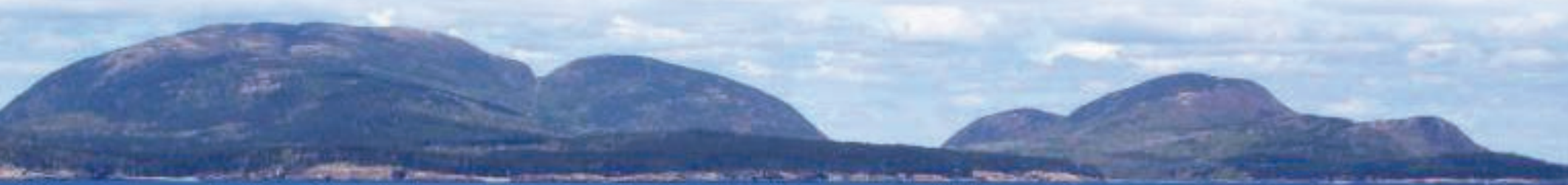

